\title{
1,1,1-Trifluoropropan-2-ammonium triflate: stereoselective synthesis and direct use in reaction with epoxides
}

\author{
Gemma Packer, Julien Malassis, Neil Wells, Mark Light, and Bruno Linclau* \\ Chemistry, University of Southampton, Highfield, Southampton SO17 1BJ, United Kingdom.
}

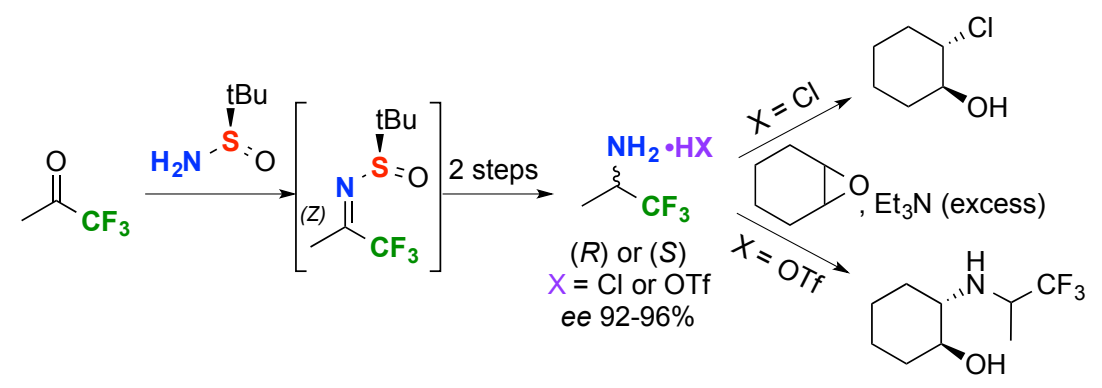

\begin{abstract}
A three-step synthesis of enantiomerically enriched 1,1,1-trifluoro-2-propanamine based on the use of a chiral sulfinamide auxiliary is described. Reduction of the geometrically pure $Z$-sulfinimine (NOE, $\mathrm{HOE}$ ) with $\mathrm{NaBH}_{4}$ or L-selectride leads to the corresponding $(R)$ - or $(S)$-configured amine derivatives (X-ray crystallographic analysis) in $92-96 \% d e$. The typical models to explain stereoselection for these reducing agents fail to rationalize the obtained stereoselectivities, and in situ imine isomerization is proposed to occur. The direct use of the hydrochloric acid salt (with excess $\mathrm{Et}_{3} \mathrm{~N}$ ) of this poorly nucleophilic amine for epoxide opening reactions is not possible due to faster reaction of chloride. Hence, a novel triflate salt is introduced, synthesized through facile sulfinamide hydrolysis with trimethylsilyl triflate, which can be used directly, without the need of isolating the pure amine beforehand.
\end{abstract}

Keywords: organofluorine chemistry, chiral amines, epoxide opening, sulfinamide auxiliary, trifluoromethyl

\section{Introduction}

1,1,1-Trifluoropropan-2-amine (trifluoroisopropylamine) $\mathbf{1}$ is a valuable fluorinated building block. Both enantiomers and the racemic mixture are commercially available, if expensive. The enantiomers are synthesized on industrial scale by $\mathrm{SF}_{4}$-mediated fluorination of $\mathrm{D}$ - and L-alanine. ${ }^{1}$ The toxicity issues associated with gaseous $\mathrm{SF}_{4}$ requires the use of specialized facilities, resulting in the high commercial value of this building block, and has spurred alternative synthetic methodologies compatible with standard laboratories.

Racemic 1 can be synthesized from the corresponding oxime via high pressure reduction, ${ }^{2,3}$ or by base-catalyzed isomerization of the benzyl imine of 1,1,1-trifluoroacetone. ${ }^{4}$ Resolution of racemic $\mathbf{1}$ is possible via crystallization with enantiopure tartaric $\operatorname{acid}^{5}$ (up to $99 \%$ ee). ${ }^{6}$ There are several enantioselective syntheses reported that employ chirality transfer. A seminal procedure introduced by Soloshonok involving the use of enantiopure 1-phenylethylamine in conjunction with the aforementioned base-catalysed imine isomerization, ${ }^{6,7}$ which typically leads to $92-93 \% e e$, is the most used. An organocatalytic isomerization procedure starting from achiral benzyl imine is also reported $(90 \% e e){ }^{8}$ The Bravo group reported two methods based on a chiral sulfoxide, either starting from trifluoroacetic acid or from trifluoroacetaldehyde, which led to enantiopure $\mathbf{1}$ thanks to possible diastereomeric separations of intermediates.,10 However, these routes are quite lengthy.

Based on the above, we were interested to investigate the enantioselective formation of $\mathbf{1}$ using the Ellman sulfinamide auxiliary. ${ }^{11}$ Key precedence includes the formation of the corresponding imine 5a (Scheme 1) as an intermediate for the synthesis of trifluoromethylated amino acids, ${ }^{12,13}$ as well as the formation and stereoselective reduction of trifluoromethylated imines 5b-d. ${ }^{14,15,16}$ There are other examples of sulfinimine formation from trifluoromethyl ketones. ${ }^{17-20}$

The $N$-sulfinylimine 5a was reported to be unstable/prone to hydrolysis, but could be efficiently trapped with cyanide (Scheme 1 (a)). ${ }^{12}$ Interestingly, Grellepois showed that the unstable 5a could be easily isolated as the hemiaminal 6, which, when submitted to a Reformatski reaction in THF, slowly released 5a before reacting with the zinc/copper enolate (Scheme 1 (b)). ${ }^{13}$ In contrast, conjugated imines $\mathbf{5 b}$ proved to be stable and isolable (Scheme 1 (c)). Reduction of sulfinimines $\mathbf{5 b - d}$ proved to proceed with excellent diastereoselectivities (Scheme 1, (c-e)), with the relative configuration of the formed amine center depending on the nature of the reducing agent used. Whereas the geometry of 
$\mathbf{5 a},{ }^{10} \mathbf{5} \mathbf{c},{ }^{13} \mathbf{5} \mathbf{d}^{16}$ was not established, the geometry of one conjugated unsaturated imine $\mathbf{5 b}(\mathrm{R}=p$-tolyl) was proven via $\mathrm{X}$ ray crystallographic analysis. ${ }^{14}$

Herein we describe our results in applying this methodology towards the synthesis of enantioenriched 1,1,1-trifluoro-2propanamine 1, including the establishment of the geometry of the $N$-sulfinylimine $\mathbf{5 a}$, as well as of the resulting reduction products using both types of reducing agents. A model for the observed stereoselection is discussed. In addition, we report on the use of salts of the volatile $\mathbf{1}$ in epoxide opening reactions.

Scheme 1. Key precedence involving trifluoromethylated $t$-butanesulfinyl ketimines.

(a)
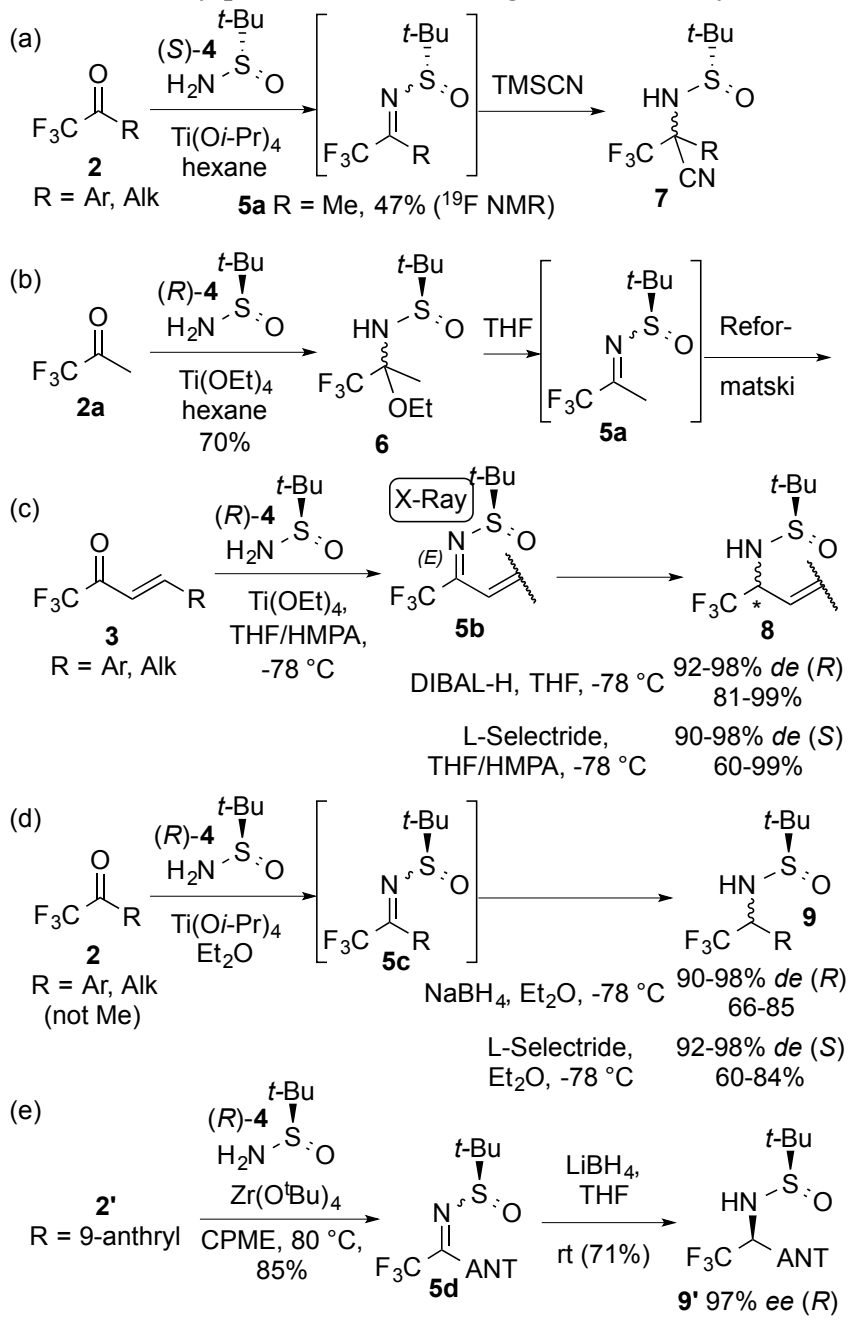

\section{Results and Discussion}

Liu's and Lu's procedures for $N$-sulfinylimine formation were initially evaluated with trifluoroacetone (Table 1 , entries 1,2). The reduction products were obtained with excellent stereoselectivities, though in low yield. The two diastereomers could be easily distinguished via ${ }^{19} \mathrm{~F}$ NMR (two doublet peaks at $\delta-78.15$ and $\delta-78.62 \mathrm{ppm}$ ), and the complete consumption of $N$-sulfinylimine 5a was evidenced by the absence of its singlet at -75.48 ppm. Unfortunately, the mixture of diastereoisomers proved inseparable by chromatography. Due to the volatility of diethyl ether and the need to conduct the reaction in a sealed tube, it was decided to continue our investigations using with non-volatile solvent, despite the better yield observed with Liu's procedure. It was found that increasing the excess of $\mathrm{NaBH}_{4}$ and addition at lower temperature (entry 3 ) led to an improved $d r$ of 96:4, although a wide range of yields was obtained (11 to $77 \%$ for 5 reactions, $55 \%$ on scale, entry 4 ), indicating issues with reproducibility. The reaction was also investigated with an excess of $\mathrm{Ti}(\mathrm{OiPr})_{4}$ in a attempt to prevent hydrolysis of the unstable imine, although this made the work up considerably more troublesome (entry 5). Subsequent reactions involving the use of DCM/MeOH as solvents for the imine formation allowed obtainment of more consistent yields (entries 6,7,9,10). Reducing the excess of auxiliary from 2 to 1.5 equiv did not impact the outcome of the reaction (entries 7,9). However, reversing the excess of reagents led to a lower yield (entry 8). Improved $d r$ 's of 97:3 and 98:2 were also found by suppressing the use of $\mathrm{MeOH}$ during the reduction (entries 9, 10). This reaction could be carried out on $5 \mathrm{~mL}$ scale of trifluoroacetone (entry 10), giving the product in $52 \%$ yield. 
The reduction with L-selectride was briefly investigated, in order to see whether a change in facial selectivity is also observed (cf Scheme 1). This proved indeed to be the case (entry 11) in high diastereoselectivity, albeit in low yield.

Table 1. Optimization experiments for imine formation and reduction.

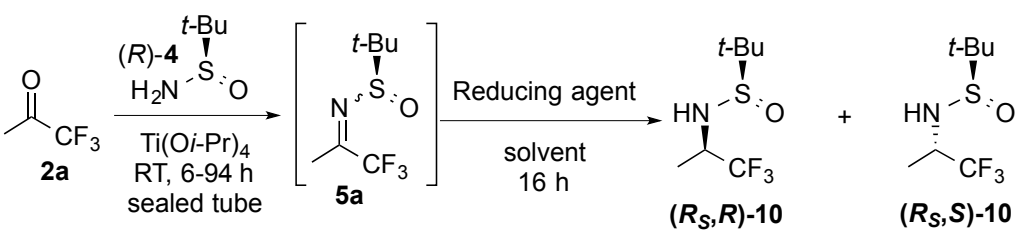

\begin{tabular}{|c|c|c|c|c|c|c|c|c|}
\hline Entry & $\begin{array}{l}\mathrm{Ti}(\mathrm{O} i \mathrm{Pr})_{4} \\
\text { (equiv) }\end{array}$ & $\begin{array}{l}\text { (R)-4 } \\
\text { (equiv) }\end{array}$ & Solvent & $\begin{array}{l}\text { Reduction } \\
\text { Temp }\left({ }^{\circ} \mathrm{C}\right)\end{array}$ & $\begin{array}{l}\text { Reagent } \\
\text { (equiv) }\end{array}$ & Solvent & $\begin{array}{l}\text { Yield } \\
(\%)\end{array}$ & $\begin{array}{l}d r \\
(R: S)\end{array}$ \\
\hline $1^{\lfloor\mathrm{a}\rfloor}$ & 2.5 & 1.25 & $\mathrm{Et}_{2} \mathrm{O}$ & -78 to $\mathrm{rt}$ & $\mathrm{NaBH}_{4}(3.0)$ & $\mathrm{Et}_{2} \mathrm{O}$ & 36 & $98: 2$ \\
\hline $2^{[\mathrm{a}]}$ & 1.5 & 1 & hexane & $0{ }^{\circ} \mathrm{C}$ to $\mathrm{rt}$ & $\mathrm{NaBH}_{4}(1.0)$ & THF/MeOH & 15 & $95: 5$ \\
\hline $3^{\lfloor\mathrm{a}\rfloor}$ & 1.5 & 2 & hexane & $-30{ }^{\circ} \mathrm{C}$ to $\mathrm{rt}$ & $\mathrm{NaBH}_{4}(3.0)$ & $\mathrm{THF} / \mathrm{MeOH}$ & $11-77$ & $96: 4$ \\
\hline $4^{\lfloor b\rfloor}$ & 1.5 & 2 & hexane & $-30{ }^{\circ} \mathrm{C}$ to $\mathrm{rt}$ & $\mathrm{NaBH}_{4}(3.0)$ & THF/MeOH & 55 & $96: 4$ \\
\hline $5^{\lfloor\mathrm{a}\rfloor}$ & 4 & 2 & hexane & $-30^{\circ} \mathrm{C}$ to $\mathrm{rt}$ & $\mathrm{NaBH}_{4}(3.0)$ & THF/MeOH & 48 & $96: 4$ \\
\hline $6^{\lfloor\mathrm{a}\rfloor}$ & 1.5 & 2 & hexane/DCM & $-30{ }^{\circ} \mathrm{C}$ to $\mathrm{rt}$ & $\mathrm{NaBH}_{4}(3.0)$ & THF/MeOH & 54 & $95: 5$ \\
\hline $7^{\lfloor\mathrm{a}\rfloor}$ & 1.5 & 1.5 & hexane/DCM & $-30{ }^{\circ} \mathrm{C}$ to $\mathrm{rt}$ & $\mathrm{NaBH}_{4}(3.0)$ & THF/MeOH & 55 & $96: 4$ \\
\hline $8^{\lfloor\mathrm{a}\rfloor}$ & 1.5 & $1^{(\mathrm{c})}$ & hexane/DCM & $-30^{\circ} \mathrm{C}$ to $\mathrm{rt}$ & $\mathrm{NaBH}_{4}(3.0)$ & THF/MeOH & 35 & $96: 4$ \\
\hline $9^{[\mathrm{a}]}$ & 1.5 & 2 & hexane/DCM & $-30{ }^{\circ} \mathrm{C}$ to $\mathrm{rt}$ & $\mathrm{NaBH}_{4}(3.0)$ & THF & 56 & $97: 3$ \\
\hline $10^{\lfloor\mathrm{b}\rfloor}$ & 1.5 & 1.5 & hexane/DCM & $-30^{\circ} \mathrm{C}$ to $\mathrm{rt}$ & $\mathrm{NaBH}_{4}(3.0)$ & THF & 52 & $98: 2$ \\
\hline $11^{[\mathrm{c}]}$ & 4 & 1.05 & THF & $-78^{\circ} \mathrm{C}$ & $\begin{array}{l}\text { L-Selectride } \\
(1.05)\end{array}$ & THF & 22 & $4: 96$ \\
\hline
\end{tabular}

a 5 mmol scale of $\mathbf{2 a}$; b $55.8 \mathrm{mmol}$ scale of $\mathbf{2 a}$. c 1.5 equiv of $\mathbf{2 a}$.

Both $N$-trifluoroisopropylsulfinamide diastereomers $\mathbf{1 0}$ were crystalline solids, but all attempts to achieve a preparatively useful separation through recrystallization were met with failure. Attempts with EtOAc/pentane as solvent did generate single crystals of both diastereomers suitable for X-ray diffraction studies (Figure 1), which allowed unambiguous determination of the relative configuration of the reduction products.

Figure 1. Crystal structures of $\left(R_{S}, \boldsymbol{R}\right)-10$ and $\left(R_{S}, S\right)-10$.

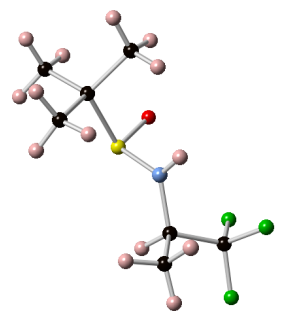

$\left(R_{S}, R\right)-10$

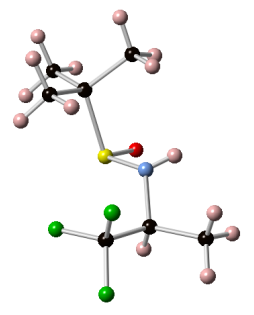

$\left(R_{S}, S\right)-10$

In order to determine the facial selectivity of the $N$-sulfinylimine reduction, the determination of the configuration of the $N$-sulfinylimine 5a was attempted. Following Lu's procedure, ${ }^{12}$ its formation was investigated in hexane. Analysis of the crude reaction mixture via ${ }^{19} \mathrm{~F}$ NMR showed the formation of a single peak at $\delta-75.48 \mathrm{ppm}\left(\mathrm{CDCl}_{3}\right)$, which 
indicated the selective formation of a single imine geometric isomer. However, NOE analysis was hampered by the presence of residual hexane and unreacted $(R)$-tert-butane sulfinamide, which obscured key resonances in the spectra. Imine formation was then investigated in $\mathrm{CH}_{2} \mathrm{Cl}_{2}$, with fewer equivalents of auxiliary. An increased amount of $\mathrm{Ti}\left(\mathrm{O}^{i} \mathrm{Pr}\right)_{4}$ (4 equiv) was also added in an attempt to contain hydrolysis. Analysis via ${ }^{19} \mathrm{~F}$ NMR after $18 \mathrm{~h}\left(\mathrm{CDCl}_{3}\right)$ showed the formation of the same geometric imine isomer previously observed and, after quenching with $\mathrm{H}_{2} \mathrm{O}$, purification was achieved via filtration under reduced pressure through a plug of silica. The sample was then immediately submitted for NOE/HOE studies (Figure 2; Supporting Information). Irradiation of the methyl or $t$-butyl peaks did not lead to any coupling (NOE), while irradiation of the trifluoromethyl peak (HOE) led to coupling with both methyl and trifluoromethyl groups. This is consistent with $Z$-geometry, opposite with what was found for the $\alpha, \beta$-unsaturated $N$ -

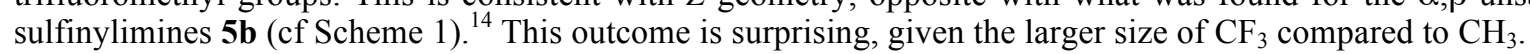

Figure 2. Imine geometry determination.

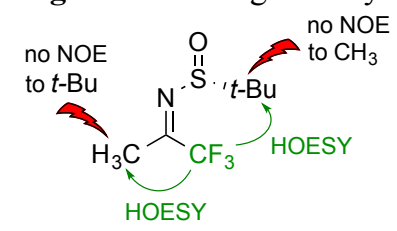

With the imine geometry and relative stereochemistry of the amines known, rationalization of the stereoselection was undertaken. Reactions of $N$-sulfinylimines with Selectride have been rationalized via an open transition state similar to TS-1 (Figure 3), ${ }^{21}$ including for the reduction of the $E$-configured $\alpha, \beta$-unsaturated sulfinimines. However, with the $Z$ configured 5a as substrate, TS-1 would lead to $\mathrm{Si}$-face attack, which is not what is observed. Possible destabilization of TS-1 by repulsion between the $\mathrm{CF}_{3}$ group and the sulfoxide oxygen could induce in situ isomerization, leading to TS-2, which now should undergo $R e$-face attack to give the observed major diastereomer $\left(\mathbf{S}_{R}, \mathbf{S}\right)$-10. Alternatively, a transition state involving a sulfinimine in the s-trans conformation could be considered as well (not shown). ${ }^{22,23}$ In contrast, $N$ sulfinylimine reduction with $\mathrm{NaBH}_{4}$ is proposed to proceed via a chelated transition state. ${ }^{17}$ With the $Z$-imine $\mathbf{5 a}$, this would give TS-3, featuring Re-face attack, which was not observed. In this case, TS-3 could be destabilized by repulsion between the sulfur lone pair of electrons and the $\mathrm{CF}_{3}$-moiety. ${ }^{15}$ Hence, in situ imine isomerization is again invoked, allowing the chelated transition state TS-4, which predicts the observed $\left(\mathrm{S}_{R}, R\right)$-diastereomer.

$N$-sulfinylimines are known to undergo rapid $E / Z$ isomerization (but with a high enough isomerization barrier as to be able to observe the individual isomers by NMR at rt), ${ }^{24,25}$ and was reported for a number of other $N$-sulfinylimine reactions. ${ }^{26-32}$ This was typically explained by invoking chelation, or through prior coordination with a Lewis acid before reaction. It was also implied by Liu to account for their observed diastereoselectivities. ${ }^{15}$ In the case of $5 \mathbf{a}$, it appears that isomerization is induced simply by unfavourable interactions in the transition state.

Figure 3. Explanation of the stereoinduction.

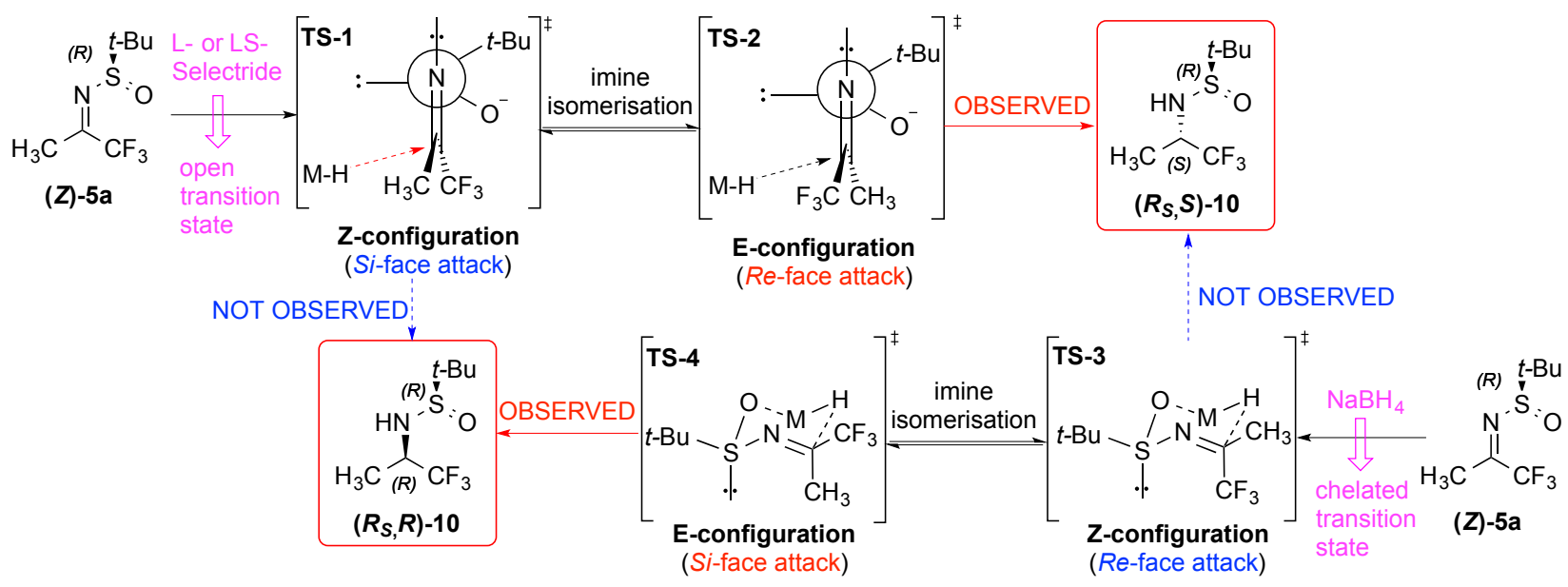

Auxiliary removal was achieved with the usual conditions to give the hydrochloric acid salt $\mathbf{1} \cdot \mathbf{H C l}(\mathrm{Scheme} 2)$, and purification via trituration with $\mathrm{Et}_{2} \mathrm{O}$ allowed its isolation as a white solid in an $89 \%$ yield (see Supporting Information for X-ray crystallographic analysis). The optical rotation $\left([\alpha]_{\mathrm{D}}-1.15, c 1.0, \mathrm{MeOH}, 23{ }^{\circ} \mathrm{C}\right.$ for $92 \%$ ee) is comparable to the value of -2.94 (c $1.0, \mathrm{MeOH}, 25{ }^{\circ} \mathrm{C}$ for $98 \%$ ee) reported by Soloshonok. ${ }^{7}$ In order to access the triflate salt (see below), we found that cleavage with TMSOTf in $\mathrm{MeOH}$, which to the best of our knowledge has not been used yet for this transformation, ${ }^{33}$ was very facile, leading to the novel triflate salt 1•OTf for which suitable crystals for X-ray crystallographic analysis were obtained (Supporting Information). Despite this combination must result in TfOH release, it was superior to $\mathrm{TfOH}$ itself which gave a lower yield (77\%, not shown), with a significant exotherm. 
Scheme 2. Auxiliary removal.

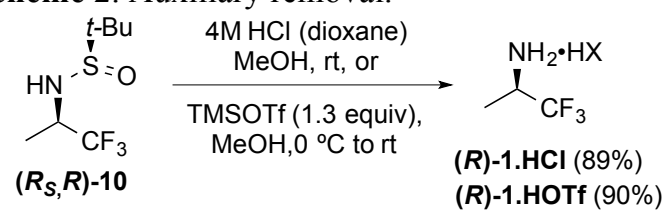

The crystalline hydrochloric acid salt is a convenient source of the volatile trifluoroisopropylamine. However, the trifluoromethyl group strongly reduces the nucleophilicity of the amino group, to the extent that $\mathbf{1}$ is much less nucleophilic than chloride. This was confirmed by an experiment (Scheme 3), in which reaction of epoxide 11 with 1•HCl in the presence of excess $\mathrm{Et}_{3} \mathrm{~N}$ essentially only gave the chlorohydrin 13a. Hence, when 1.HCl is used as starting material for nucleophilic substitution reactions, prior neutralization and isolation of $\mathbf{1}$ as free base with complete removal of chloride species is required. ${ }^{34}$ However, the volatility of $\mathbf{1}$ introduces practical difficulties, and hence it was investigated whether the corresponding triflate 1•OTf, in the presence of excess $\mathrm{Et}_{3} \mathrm{~N}$, would be a suitable trifluoroisopropylamine source to use directly in epoxide opening reactions. Pleasingly, reaction of 11 (96:4 $d r$ ) with 1•HOTf led to exclusive formation of amino alcohols 12, in 52:48 diastereomeric ratio. The obtained yield is comparable to the result obtained by Upthagrove $(22 \%)$, in which the free base was reacted with a terminal epoxide. ${ }^{34}$ Brief optimization experiments including the use of microwave irradiation (in acetonitrile as solvent), ${ }^{35}$ and the use of hexafluoroisopropanol $-\mathrm{a}$ solvent that promotes epoxide opening ${ }^{36}{ }^{36}$ were unsuccessful $(3 \%$ and $15 \%$ yield respectively).

Scheme 3. Epoxide opening starting from amine salts.

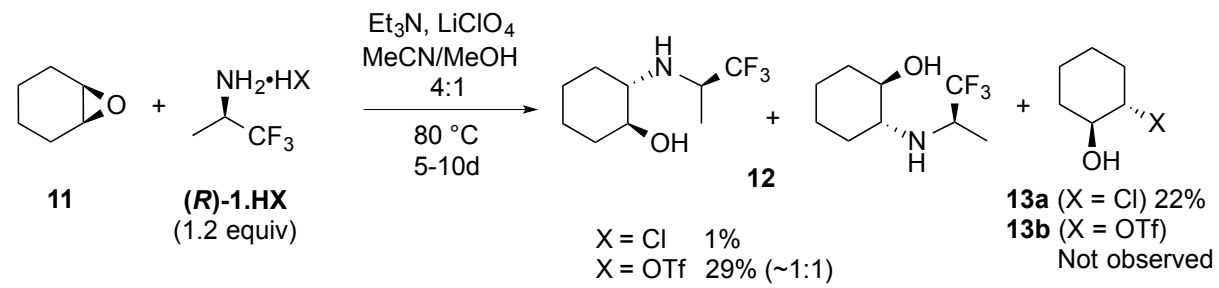

In conclusion, the enantioselective synthesis of 1,1,1-trifluoropropan-2-amine was achieved starting from trifluoroacetone using the sulfinamide auxiliary. The intermediate imine proved too unstable to isolate, but NOE and HOESY experiments established its $Z$-geometry. This is only the second example of determination of imine geometry derived from trifluoromethyl ketones, the other case being an $\alpha, \beta$-unsaturated derivative having the $E$-configuration. ${ }^{14}$ An in-situ imine formation/reduction protocol with $\mathrm{NaBH}_{4}$ proceeded in high diastereoselectivity (96\% de), which represents a slight improvement over previous methods. Reaction with L-selectride gave the opposite facial attack. Xray crystallographic analysis of the reduction products unambiguously established their relative configuration. While the change in facial selectivity between these reducing agents was expected based on existing models for stereoselection, in situ sulfinimine isomerization to the $E$-isomer has to be invoked in order to explain stereoselection. It was shown that TMSOTf in $\mathrm{MeOH}$ is an excellent reagent combination for auxiliary removal, which led to the synthesis of the novel trifluoroisopropylammonium triflate salt, which could be used directly as a convenient source of trifluoroisopropylamine in a nucleophilic substitution reaction (excess $\mathrm{Et}_{3} \mathrm{~N}$ ) without competing reaction of the triflate anion. Given the importance of fluorination in drug development ${ }^{38-41}$ and agrochemical industry, ${ }^{42,43}$ this work will be of general interest in the biosciences.

\section{Experimental Section}

$\left(R_{S}, Z\right)-N$-(1,1,1-trifluoro-2-propylidene)-t-butanesulfinamide (5a). Trifluoroacetone $(0.23 \mathrm{~mL}, 2.50 \mathrm{mmol})$ was cooled to $-40{ }^{\circ} \mathrm{C}$ in a dry ice/acetone bath and cannulated into a sealed tube containing $\mathrm{CH}_{2} \mathrm{Cl}_{2}(0.5 \mathrm{~mL})$. (R)-tertbutanesulfinamide $(0.32 \mathrm{~g}, 2.63 \mathrm{mmol}), \mathrm{Ti}\left(\mathrm{O}^{i} \mathrm{Pr}\right)_{4}(2.96 \mathrm{~mL}, 10.0 \mathrm{mmol})$ and the remaining $\mathrm{CH}_{2} \mathrm{Cl}_{2}(0.6 \mathrm{~mL})$ added, the tube sealed and the reaction stirred at RT for $18 \mathrm{~h}$. Upon completion the reaction was transferred to a larger vessel and quenched via dropwise addition of $\mathrm{H}_{2} \mathrm{O}(2.5 \mathrm{~mL})$ whilst being rapidly stirred. The quenched reaction was allowed to stir for $5 \mathrm{~m}$, followed by filtration through a pad of $\mathrm{MgSO}_{4} /$ celite and concentrated in vacuo to yield a yellow oil. The resultant oil was partially purified via filtration through a plug of silica under reduced pressure (isocratic elution of petrol/EtOAc, 5\%), concentrated in vacuo and a sample submitted directly for NMR studies. ${ }^{1} \mathbf{H}$ NMR (500 MHz, $\left.\mathrm{CDCl}_{3}\right): \delta 2.52\left(3 \mathrm{H}\right.$, br. d, $\left.J 0.3 \mathrm{~Hz}, \mathrm{CH}_{3} \mathrm{CCF}_{3}\right), 1.31\left(9 \mathrm{H}, \mathrm{s}, 3 \times \mathrm{CH}_{3}\right)$ ppm; ${ }^{19} \mathbf{F}$ NMR $\left(471 \mathrm{MHz}, \mathrm{CDCl}_{3}\right): \delta-75.23(3 \mathrm{~F}$, $\left.\mathrm{s}, \mathrm{CF}_{3}\right) \mathrm{ppm}$. 
$\left(R_{S}\right)-N$-((2R)-1,1,1-trifluoroprop-2-yl)-t-butanesulfinamide $\left(\left(\boldsymbol{R}_{S}, \boldsymbol{R}\right)\right.$-10). Synthesis on 56 mmol scale (Table 1, entry 10). Trifluoroacetone $\left(5 \mathrm{~mL}, 55.8 \mathrm{mmol}, 1\right.$ equiv) was cooled down to $-40{ }^{\circ} \mathrm{C}$ in a card ice/acetone bath and then added via syringe to a sealed flask fitted with an argon balloon and containing dry hexane $(50 \mathrm{~mL})$, previously placed in an ice

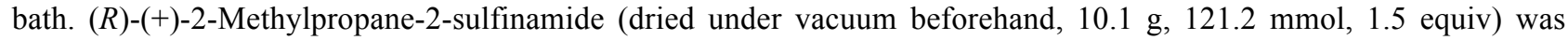
then added at $0{ }^{\circ} \mathrm{C}$, and the flask was rinsed with dry $\mathrm{CH}_{2} \mathrm{Cl}_{2}(50 \mathrm{~mL})$. Titanium isopropoxide $(25 \mathrm{~mL}, 83.7 \mathrm{mmol}, 1.5$ equiv) was added at $0{ }^{\circ} \mathrm{C}$, and the flask was fitted with its corresponding screw top lid. The resulting mixture was allowed to warm up to rt and stirred for $48 \mathrm{~h}$. Reaction mixture was then cooled down to $-30{ }^{\circ} \mathrm{C}$, and flushed with an argon balloon, and THF $(70 \mathrm{~mL})$ was added, followed by $\mathrm{NaBH}_{4}(6.2 \mathrm{~g}, 164.5 \mathrm{mmol}, 3.0$ equiv). The mixture was stirred at $-30{ }^{\circ} \mathrm{C}$ for $0.5 \mathrm{~h}$, and then allowed to warm up to $\mathrm{rt}$ and stirred overnight.

The reaction was cooled to $0{ }^{\circ} \mathrm{C}$ with vigorous stirring. Water $(60 \mathrm{~mL})$ was added dropwise and the reaction stirred for $10 \mathrm{~min}$. The reaction mixture was filtered through celite and the filter cake was washed with $\mathrm{CH}_{2} \mathrm{Cl}_{2}$. The resulting mixture was evaporated under reduced pressure to give a white solid. The latter was partitioned between $\mathrm{CH}_{2} \mathrm{Cl}_{2}(100$ $\mathrm{mL})$ and a saturated solution of $\mathrm{NH}_{4} \mathrm{Cl}(60 \mathrm{~mL})$. Phases were separated, and $10 \mathrm{~mL}$ of $\mathrm{HCl}(2 \mathrm{M})$ was added to the aqueous phase, which was back extracted with $\mathrm{CH}_{2} \mathrm{Cl}_{2}(3 \times 50 \mathrm{~mL})$. Brine was eventually added during the extraction process to facilitate decantation. Organic phases were combined, dried over $\mathrm{MgSO}_{4}$ and concentrated to give the crude $\alpha$-trifluorosulfinamide as a mixture of diastereoisomers ( $d r$ 98:2). Column chromatography (petroleum ether/EtOAc $85: 15$ to $6: 4)$ afforded the expected product as a colorless oil $(6.3 \mathrm{~g}, 52 \%)$. The column was then eluted with acetone to recover the excess $(R)-(+)-2-m e t h y l p r o p a n e-2-s u l f i n a m i d e ~(3.3 \mathrm{~g})$. mp 35-37 ${ }^{\circ} \mathrm{C}$ (EtOAc/petrol, $96: 4$ sample). Rf 0.51 $\left(\mathrm{MeOH} / \mathrm{CH}_{2} \mathrm{Cl}_{2} 10: 90\right)$. $[\alpha]_{\mathrm{D}}-70.4\left(c 0.99, \mathrm{CHCl}_{3}, 22^{\circ} \mathrm{C}, 96: 4\right.$ sample). IR $\left(\mathrm{cm}^{-1}\right) 3197(\mathrm{~N}-\mathrm{H}), 2955(\mathrm{C}-\mathrm{H}), 1365,1273$ $(\mathrm{S}=\mathrm{O}), 1175(\mathrm{C}-\mathrm{N}), 1054(\mathrm{C}-\mathrm{F}) .{ }^{1} \mathbf{H}$ NMR $\left(500 \mathrm{MHz}, \mathrm{CDCl}_{3}\right): \delta 3.86\left(1 \mathrm{H}\right.$, app. dsept, J 7.0, $\left.6.8 \mathrm{~Hz}, \mathrm{CHCF}_{3}\right), 3.58(1 \mathrm{H}$, br. d, $J 5.8 \mathrm{~Hz}, \mathrm{NH}), 1.46\left(3 \mathrm{H}, \mathrm{dq}, J 6.9,0.6 \mathrm{~Hz}, \mathrm{CH}_{3} \mathrm{CHCF}_{3}\right), 1.24\left(9 \mathrm{H}, \mathrm{s}, 3 \times \mathrm{CH}_{3}\right) \mathrm{ppm} .{ }^{1} \mathbf{H}\left\{{ }^{1 \mathbf{9}} \mathbf{F}\right\} \mathbf{N M R}(500 \mathrm{MHz}$, $\left.\mathrm{CDCl}_{3}\right): \delta 3.87\left(1 \mathrm{H}\right.$, app. quint, $\left.J 6.8 \mathrm{~Hz}, \mathrm{CHCF}_{3}\right), 3.58(1 \mathrm{H}$, br. d, $J 6.0 \mathrm{~Hz}, \mathrm{NH}), 1.46\left(3 \mathrm{H}, \mathrm{d}, J 6.8 \mathrm{~Hz}, \mathrm{CH}_{3} \mathrm{CHCF}_{3}\right)$, $1.24\left(9 \mathrm{H}, \mathrm{s}, 3 \times \mathrm{CH}_{3}\right)$ ppm. ${ }^{1} \mathbf{H}\left\{{ }^{19} \mathbf{F}\right\}$ NMR $\left(500 \mathrm{MHz}, \mathrm{CDCl}_{3}+\mathrm{D}_{2} \mathrm{O}\right.$ exchange): $\delta 3.87\left(1 \mathrm{H}, \mathrm{q}, J 6.8 \mathrm{~Hz}, \mathrm{CHCF}_{3}\right), 1.45$ $\left(3 \mathrm{H}, \mathrm{d}, J 6.8 \mathrm{~Hz}, \mathrm{CH}_{3} \mathrm{CHCF}_{3}\right), 1.24\left(9 \mathrm{H}, \mathrm{s}, 3 \times \mathrm{CH}_{3}\right) \mathrm{ppm} .{ }^{13} \mathbf{C} \mathbf{N M R}\left(125 \mathrm{MHz}, \mathrm{CDCl}_{3}\right): \delta 125.4\left(\mathrm{CF}_{3}, \mathrm{q}, J 281.1 \mathrm{~Hz}\right)$, $56.4\left(\mathrm{~S}(\mathrm{O}) \mathrm{C}\left(\mathrm{CH}_{3}\right)_{3}\right), 52.6\left(\mathrm{CHCF}_{3}, \mathrm{q}, J 30.8 \mathrm{~Hz}\right), 22.3\left(3 \times \mathrm{CH}_{3}\right), 14.3\left(\mathrm{CH}_{3} \mathrm{CHCF}_{3}, \mathrm{q}, J 2.1 \mathrm{~Hz}\right) \mathrm{ppm} .{ }^{19} \mathbf{F}$ NMR $(471$ $\left.\mathrm{MHz}, \mathrm{CDCl}_{3}\right): \delta-77.81\left(3 \mathrm{~F}, \mathrm{~d}, J 7.0 \mathrm{~Hz}, \mathrm{CF}_{3}\right) \mathrm{ppm} .{ }^{19} \mathbf{F}\left\{{ }^{1} \mathbf{H}\right\}$ NMR $\left(376 \mathrm{MHz}^{\mathrm{N}} \mathrm{CDCl}_{3}\right): \delta-78.06\left(3 \mathrm{~F}, \mathrm{~s}, \mathrm{CF}_{3}\right) \mathrm{ppm} . \mathbf{M S}$ $\left(\mathrm{ESI}^{+}\right) \mathrm{m} / \mathrm{z}(\%): 218[\mathrm{M}+\mathrm{H}]^{+}(100), 240[\mathrm{M}+\mathrm{Na}]^{+}(12), 435[2 \mathrm{M}+\mathrm{H}]^{+}$(15). HRMS $\left(\mathrm{ESI}^{+}\right)$for $\mathrm{C}_{7} \mathrm{H}_{15} \mathrm{~F}_{3} \mathrm{NOS}[\mathrm{M}+\mathrm{H}]^{+}$ calcd. 218.0821 , found 218.0824 .

$\left(R_{S}\right)$-N-((2S)-1,1,1-trifluoroprop-2-yl)-t-butanesulfinamide $\left(\left(\boldsymbol{R}_{S}, \boldsymbol{S}\right)\right.$-10). Trifluoroacetone $(0.23 \mathrm{~mL}, 2.50 \mathrm{mmol})$ was cooled to $-40{ }^{\circ} \mathrm{C}$ in a cardice/acetone bath and cannulated into a sealed tube containing THF $(1 \mathrm{~mL})$. (R)-tertbutanesulfinamide $(0.32 \mathrm{~g}, 2.63 \mathrm{mmol}), \mathrm{Ti}\left(\mathrm{O}^{i} \mathrm{Pr}\right)_{4}(2.96 \mathrm{~mL}, 10.00 \mathrm{mmol})$ and the remaining $\mathrm{THF}(1.3 \mathrm{~mL})$ added, the tube sealed and the reaction stirred at RT for $40 \mathrm{~h}$. Reaction mixture was cooled to $-78{ }^{\circ} \mathrm{C}, 1 \mathrm{M}$ L-Selectride in THF $(2.62 \mathrm{~mL}, 2.63 \mathrm{mmol})$ added and the reaction mixture stirred at $-78{ }^{\circ} \mathrm{C}$ for $1 \mathrm{~h}$. Upon completion the reaction was quenched via dropwise addition of sat. $\mathrm{NH}_{4} \mathrm{Cl}(3 \mathrm{~mL})$. The reaction was filtered through a pad of $\mathrm{MgSO}_{4} / \mathrm{celite}$, washing with $\mathrm{CH}_{2} \mathrm{Cl}_{2}$, and concentrated in vacuo to yield the crude $\alpha$-trifluorosulfinamide as a mixture of diastereoisomers ( $d r 6: 94)$, as a yellow oil. The resultant oil was purified by column chromatography (isocratic elution of pentane/EtOAc 70:30) to yield $\left(\boldsymbol{R}_{S}, \boldsymbol{S}\right)$-10 as a clear syrup which crystallized upon standing $(0.12 \mathrm{~g}, 22 \%, 7: 93$ d.r. $)$. mp $82-85^{\circ} \mathrm{C}$ (EtOAc/petrol). Rf $0.51\left(\mathrm{MeOH} / \mathrm{CH}_{2} \mathrm{Cl}_{2} 10: 90\right)$. [ $\left.\alpha\right]_{\mathrm{D}}-68.8\left(c 0.99, \mathrm{CHCl}_{3}, 22^{\circ} \mathrm{C}\right)$. IR $\left(\mathrm{cm}^{-1}\right) 3167(\mathrm{~N}-\mathrm{H})$, $2977(\mathrm{C}-\mathrm{H}), 1364,1279(\mathrm{~S}=\mathrm{O}), 1171(\mathrm{C}-\mathrm{N}), 1054(\mathrm{C}-\mathrm{F}) .{ }^{1} \mathbf{H}$ NMR $\left(500 \mathrm{MHz}, \mathrm{CDCl}_{3}\right): \delta 3.85(1 \mathrm{H}$, app. dsept, $J 7.5$, $\left.7.0 \mathrm{~Hz}, \mathrm{CHCF}_{3}\right), 3.14(1 \mathrm{H}$, br. d, $J 7.5 \mathrm{~Hz}, \mathrm{NH}), 1.47\left(3 \mathrm{H}\right.$, br. dq, $\left.J 6.9,0.4 \mathrm{~Hz}, \mathrm{CH}_{3} \mathrm{CHCF}_{3}\right), 1.24\left(9 \mathrm{H}, \mathrm{s}, 3 \times \mathrm{CH}_{3}\right) \mathrm{ppm}$. ${ }^{1} \mathrm{H}$ NMR $\left(500 \mathrm{MHz}, \mathrm{CDCl}_{3}+\mathrm{D}_{2} \mathrm{O}\right.$ exchange): $\delta 3.84\left(1 \mathrm{H}\right.$, app. sept, $\left.J 7.0 \mathrm{~Hz}, \overline{\mathrm{CHCF}}_{3}\right), 1.47(3 \mathrm{H}, \mathrm{dq}, J 7.0,0.6 \mathrm{~Hz}$, $\left.\mathrm{CH}_{3} \mathrm{CHCF}_{3}\right), 1.24\left(9 \mathrm{H}, \mathrm{s}, 3 \times \mathrm{CH}_{3}\right) \mathrm{ppm} .{ }^{1} \mathbf{H}\left\{{ }^{19} \mathbf{F}\right\}$ NMR $\left(500 \mathrm{MHz}, \mathrm{CDCl}_{3}\right): \delta 3.85\left(1 \mathrm{H}, \mathrm{dq}, J 7.8,7.0 \mathrm{~Hz}_{1} \mathrm{CHCF}_{3}\right), 3.14$ $\left(1 \mathrm{H}\right.$, br. d, J 7.4 Hz, NH), $1.48\left(3 \mathrm{H}, \mathrm{d}, J 6.9 \mathrm{~Hz}, \mathrm{CH}_{3} \mathrm{CHCF}_{3}\right), 1.24\left(9 \mathrm{H}, \mathrm{s}, 3 \times \mathrm{CH}_{3}\right)$ ppm. ${ }^{1} \mathbf{H}\left\{{ }^{19} \mathbf{F}\right\} \mathbf{N M R}(500 \mathrm{MHz}$, $\mathrm{CDCl}_{3}+\mathrm{D}_{2} \mathrm{O}$ exchange): $\delta 3.84\left(1 \mathrm{H}, \mathrm{q}, J 6.9 \mathrm{~Hz}, \overline{\mathrm{CHCF}}_{3}\right), 1.48\left(3 \mathrm{H}, \mathrm{d}, J 6.9 \mathrm{~Hz}, \mathrm{CH}_{3} \mathrm{CHCF}_{3}\right), 1.24\left(9 \mathrm{H}, \mathrm{s}, 3 \times \mathrm{CH}_{3}\right)$ ppm. ${ }^{13} \mathrm{C}$ NMR $\left(125 \mathrm{MHz}, \mathrm{CDCl}_{3}\right): \delta 125.3\left(\mathrm{CF}_{3}, \mathrm{q}, J 280.4 \mathrm{~Hz}\right), 56.7\left(\mathrm{~S}(\mathrm{O}) \mathrm{C}\left(\mathrm{CH}_{3}\right)_{3}\right), 54.5\left(\mathrm{CHCF}_{3}, \mathrm{q}, J 31.1 \mathrm{~Hz}\right)$, $22.3\left(3 \times \mathrm{CH}_{3}\right), 16.5\left(\mathrm{CH}_{3} \mathrm{CHCF}_{3}, \mathrm{q}, J 2.1 \mathrm{~Hz}\right) \mathrm{ppm} .{ }^{1} \mathbf{F}$ NMR $\left(376 \mathrm{MHz}, \mathrm{CDCl}_{3}\right): \delta-78.53\left(3 \mathrm{~F}, \mathrm{~d}, J 6.9 \mathrm{~Hz}, \mathrm{CF}_{3}\right) \mathrm{ppm}$. ${ }^{19} \mathbf{F}\left\{{ }^{1} \mathbf{H}\right\}$ NMR $\left(471 \mathrm{MHz}, \mathrm{CDCl}_{3}\right): \delta-78.28\left(3 \mathrm{~F}, \mathrm{~s}, \mathrm{CF}_{3}\right) \mathrm{ppm}$. MS $\left(\mathrm{ESI}^{+}\right) \mathrm{m} / \mathrm{z}(\%): 218[\mathrm{M}+\mathrm{H}]^{+}(100) . \mathbf{H R M S}\left(\mathrm{ESI}{ }^{+}\right)$ for $\mathrm{C}_{7} \mathrm{H}_{15} \mathrm{~F}_{3} \mathrm{NOS}[\mathrm{M}+\mathrm{H}]^{+}$calcd. 218.0821, found 218.0821 .

(R)-1,1,1-Trifluoro-2-propanamine hydrochloride $(\mathbf{1} \cdot \mathbf{H C l})$. To a stirred solution of $\left(\boldsymbol{R}_{S}, \boldsymbol{R}\right)-\mathbf{1 0}(0.56 \mathrm{~g}, 2.58 \mathrm{mmol}, 96: 4$ d.r.) in $\mathrm{MeOH}(3.4 \mathrm{~mL})$ was added dropwise a $4 \mathrm{M} \mathrm{HCl}$ in dioxane solution $(2.60 \mathrm{~mL}, 10.31 \mathrm{mmol})$ and the reaction stirred at RT for $30 \mathrm{~m}$. Upon completion the reaction was concentrated in vacuo to yield a solid/residue. $\mathrm{Et}_{2} \mathrm{O}(15 \mathrm{~mL})$ was added to the resultant solid/reside in order to precipitate $(\boldsymbol{R}) \mathbf{- 1} \cdot \mathbf{H C l}$, which was filtered and washed with $\mathrm{Et}_{2} \mathrm{O}(2 \times 5$ $\mathrm{mL})$ to yield $(\boldsymbol{R}) \mathbf{- 1} \cdot \mathbf{H C l}$ as a white solid $(341.6 \mathrm{mg}, 89 \%, 92 \% e e)$. $\mathbf{R f} 0.77\left(\mathrm{CH}_{2} \mathrm{Cl}_{2} / \mathrm{MeOH} 90: 10\right)$. $[\alpha]_{\mathrm{D}}-1.15(c 1.0$, $\mathrm{MeOH}, 23{ }^{\circ} \mathrm{C}$ ), lit. $^{7}-2.94$ (c 1.0, MeOH, $25{ }^{\circ} \mathrm{C}$ for $98 \%$ ee). ${ }^{1} \mathbf{H}$ NMR (500 MHz, MeOD): $\delta 4.21$ (1H, app. sept, $J 7.0$ $\left.\mathrm{Hz}, \mathrm{CHCF}_{3}\right), 1.51\left(3 \mathrm{H}\right.$, br. dd, $\left.J 6.9,0.5 \mathrm{~Hz}, \mathrm{CH}_{3} \mathrm{CHCF}_{3}\right)$ ppm. ${ }^{1} \mathbf{H}\left\{{ }^{19} \mathbf{F}\right\}$ NMR $(500 \mathrm{MHz}, \mathrm{MeOD}): \delta 4.21(1 \mathrm{H}, \mathrm{q}, J 6.9$ $\left.\mathrm{Hz}, \mathrm{CHCF}_{3}\right), 1.51\left(3 \mathrm{H}, \mathrm{d}, J 6.9 \mathrm{~Hz}, \mathrm{CH}_{3} \mathrm{CHCF}_{3}\right) \mathrm{ppm} .{ }^{13} \mathbf{C}$ NMR $(125 \mathrm{MHz}, \mathrm{MeOD}): \delta 125.7\left(\mathrm{CF}_{3}, \mathrm{q}, J 279.3 \mathrm{~Hz}\right), 49.9$ $\left(\mathrm{CHCF}_{3}, \mathrm{q}, J 32.5 \mathrm{~Hz}\right), 12.6\left(\mathrm{CH}_{3} \mathrm{CHCF}_{3}, \mathrm{q}, J 2.1 \mathrm{~Hz}\right) \mathrm{ppm} .{ }^{19} \mathbf{F}$ NMR $(471 \mathrm{MHz}, \mathrm{MeOD}): \delta-77.97 \mathrm{(3F}, \mathrm{d}, J 7.0 \mathrm{~Hz}$, $\mathrm{CF}_{3}$ ) ppm. NMR data correspond to those previously reported. ${ }^{8}$ An analytical sample of $\mathbf{1} \cdot \mathbf{H C l}$ was recrystallized from hot $\mathrm{MeCN}$ by slow evaporation, giving suitable crystals for X-ray diffraction (see Supporting Information).

(R)-1,1,1-Trifluoro-2-propanamine hydrogen triflate $(\mathbf{1} \bullet \boldsymbol{H O T f})$. To a solution of $\alpha$-trifluorosulfinamide $\left(\boldsymbol{R}_{\boldsymbol{S}}, \boldsymbol{R}\right)-\mathbf{1 0}(738$ $\mathrm{mg}, 3.34 \mathrm{mmol}, 1$ equiv, $d r$ 98:2) in dry $\mathrm{MeOH}(6.5 \mathrm{~mL})$ at $0{ }^{\circ} \mathrm{C}$ was added TMSOTf $(800 \mu \mathrm{L}, 4.4 \mathrm{mmol}, 1.3 \mathrm{equiv})$ 
dropwise. The mixture was allowed to warm up to $\mathrm{rt}$ and stirred for $21 \mathrm{~h}$, before concentrating under vacuum. Purification via column chromatography $\left(\mathrm{CH}_{2} \mathrm{Cl}_{2} / \mathrm{MeOH}\right.$ 95:5 to 9:1) afforded a wet solid, which was then washed with $\mathrm{Et}_{2} \mathrm{O}$ to give the $\alpha$-trifluoroamine as a white solid (803 $\mathrm{mg}, 90 \%$, ee $96 \%$, estimated from the 98:2 $d r$ of 10). An analytical sample of 1•HOTf was recrystallized by slow evaporation of $\mathrm{MeOH}$, giving suitable crystals for x-ray diffraction. $[\alpha]_{\mathrm{D}} 0.31$ (c 0.64, $\left.\mathrm{MeOH}, 22{ }^{\circ} \mathrm{C}\right), \mathrm{mp} 167-170{ }^{\circ} \mathrm{C}(\mathrm{MeOH}), \mathrm{R}_{\mathrm{f}}\left(\mathrm{CH}_{2} \mathrm{Cl}_{2} / \mathrm{MeOH}\right.$ 90:10) 0.06 (revealed with vanillin); IR (neat) 3449 (m, br.), 3005 (w.), 2543 (w., br.), 1275 (s), 1260 (s) cm ${ }^{-1} ;{ }^{1} \mathrm{H}$ NMR (400 MHz, methanol-d $\left.{ }_{4}\right) \delta$ $4.19\left(1 \mathrm{H}\right.$, app. spt, $\left.J 7.0 \mathrm{~Hz}, \mathrm{CH}_{3}\right), 1.49\left(3 \mathrm{H}, \mathrm{d},{ }^{3} J_{\mathrm{HH}} 6.9 \mathrm{~Hz}, \mathrm{CH}\right) \mathrm{ppm} ;{ }^{13} \mathrm{C}$ NMR $\left(101 \mathrm{MHz}\right.$, methanol-d $\left.\mathrm{d}_{4}\right) \delta 121.8(\mathrm{q}$, $\left.{ }^{1} J_{\mathrm{CF}} 317.9 \mathrm{~Hz}, \underline{\mathbf{C F}}_{3 \mathrm{TfOH}}\right), 125.6\left(\mathrm{q},{ }^{1} J_{\mathrm{CF}} 279.3 \mathrm{~Hz}, \underline{\mathbf{C F}}_{3 \text { amine }}\right), 49.9$ (dd, ${ }^{2} J_{\mathrm{CF}} 66.8 \mathrm{~Hz},{ }^{2} J_{\mathrm{CF}} 33.0 \mathrm{~Hz}$, CH, overlapped with the solvent peak), 12.5 (q, $\left.{ }^{3} J_{\mathrm{CF}} 2.2 \mathrm{~Hz}, \underline{\mathbf{C H}}_{3}\right) \mathrm{ppm} ;{ }^{19} \mathrm{~F}$ NMR $\left(376 \mathrm{MHz}\right.$, methanol-d $\left.{ }_{4}\right) \delta-77.4\left(3 \mathrm{~F}, \mathrm{~d},{ }^{3} J_{\mathrm{FH}} 6.9 \mathrm{~Hz}, \mathrm{CF} \underline{F}_{3}\right.$ amine); - 79.5 (3F, s, $\left.\underline{\mathbf{C F}}_{3 \mathrm{TfOH}}\right) \mathrm{ppm}$.

Epoxide opening with $\mathbf{1} \cdot \mathbf{H C l}$. To a sealed tube fitted with a septum and an argon balloon were successively added the $\alpha$ trifluoroisopropylammonium chloride salt $\mathbf{1} \cdot \mathbf{H C l}\left(151 \mathrm{mg}, 1.0 \mathrm{mmol}, 1.2\right.$ equiv), $\mathrm{MeCN}(2.8 \mathrm{~mL}), \mathrm{Et}_{3} \mathrm{~N}(234 \mu \mathrm{L}, 1.68$ mmol, 2 equiv) and $\mathrm{MeOH}(0.5 \mathrm{~mL})$ at $\mathrm{rt}$. The mixture was stirred for $30 \mathrm{~min}$, after which cyclohexene oxide $11(85 \mu \mathrm{L}$, $0.84 \mathrm{mmol}, 1$ equiv) was added, followed by $\mathrm{LiClO}_{4}(179 \mathrm{mg}, 1.68 \mathrm{mmol}, 2$ equiv). The sealed tube was fitted with its corresponding lid, and the reaction was stirred at $80{ }^{\circ} \mathrm{C}$ for 5 days, then allowed to warm up to rt and stiired for 5 more days. Following this, the reaction mixture was concentrated under vacuum. The crude product was re-dissolved in $\mathrm{CH}_{2} \mathrm{Cl}_{2}(10 \mathrm{~mL})$, washed with $\mathrm{H}_{2} \mathrm{O}(1 \times 10 \mathrm{~mL})$. Aqueous phase extracted with $\mathrm{CH}_{2} \mathrm{Cl}_{2}(3 \times 10 \mathrm{~mL})$. The organic layers were combined, dried over $\mathrm{MgSO}_{4}$, and concentrated under reduced pressure to yield a brown oil. Purification by column chromatography (petroleum ether/ethyl acetate 9:1 to 7:3) gave the chlorohydrin product 13a as a yellow oil (25 $\mathrm{mg}, 22 \%)$, alongside with trace amount of the secondary amine $(\sim 1 \mathrm{mg}, \sim 1 \%) .{ }^{1} \mathrm{H} \mathrm{NMR}\left(400 \mathrm{MHz}, \mathrm{CDCl}_{3}\right) 3.73(1 \mathrm{H}$, ddd, $J 11.7,9.2,4.5 \mathrm{~Hz}), 3.51(1 \mathrm{H}, \mathrm{td}, J 9.7,4.9 \mathrm{~Hz}), 2.75-2.38(1 \mathrm{H}, \mathrm{m}), 2.29-2.17(1 \mathrm{H}, \mathrm{m}), 2.16-2.02(1 \mathrm{H}, \mathrm{m})$, $1.81-1.70(2 \mathrm{H}, \mathrm{m}), 1.70-1.56(1 \mathrm{H}, \mathrm{m}), 1.44-1.21(3 \mathrm{H}, \mathrm{m}) \mathrm{ppm} ;{ }^{13} \mathrm{C} \mathrm{NMR}\left(100 \mathrm{MHz}, \mathrm{CDCl}_{3}\right) \delta \mathrm{ppm} 75.3,67.5$, $35.1,33.1,25.6,23.9 \mathrm{ppm}$. NMR data correspond to those previously reported. ${ }^{37}$

Epoxide opening with $\mathbf{1 \bullet O T f}$. To a sealed tube fitted with a septum and an argon balloon were successively added the trifluoro isopropylammonium triflate salt 1•HOTf (265 mg, $1.0 \mathrm{mmol}, 1.2$ equiv), $\mathrm{MeCN}(2.8 \mathrm{~mL}), \mathrm{Et}_{3} \mathrm{~N}(234 \mu \mathrm{L}, 1.68$ mmol, 2 equiv), and $\mathrm{MeOH}(0.5 \mathrm{~mL})$ at rt. Mixture was stirred for $30 \mathrm{~min}$, then cyclohene oxide $11(85 \mu \mathrm{L}, 0.84 \mathrm{mmol}$, 1 equiv) was added, followed by $\mathrm{LiClO}_{4}(179 \mathrm{mg}, 1.68 \mathrm{mmol}, 2$ equiv). Sealed tube was fitted with its corresponding lid, and the reaction was stirred at $80{ }^{\circ} \mathrm{C}$ for 10 days. Following this, the reaction mixture concentrated under vacuum. The crude product was redissolved in $\mathrm{CH}_{2} \mathrm{Cl}_{2}(10 \mathrm{~mL})$, washed with $\mathrm{H}_{2} \mathrm{O}(1 \times 10 \mathrm{~mL})$. Aqueous phase extracted with $\mathrm{CH}_{2} \mathrm{Cl}_{2}(3 \times 10 \mathrm{~mL})$. The organic layers were combined, dried over $\mathrm{MgSO}_{4}$, and concentrated under reduced pressure to yield a brown oil. Purification by column chromatography (petroleum ether/EtOAc 9:1 to 7:3) gave the expected secondary amine $\mathbf{1 2}$ as a yellow oil and as a 52:48 mixture of diastereoisomers (51 mg, $29 \%$ ). Purification by preparative $\mathrm{HPLC}\left(\mathrm{CH}_{2} \mathrm{Cl}_{2} / \mathrm{MeOH} 98: 2\right)$ enabled separation and isolation of two pure fractions of each diastereoisomer, for characterisation purpose.

Data for diastereomer 1: $[\alpha]_{\mathrm{D}}+28.2\left(\mathrm{c} 0.59, \mathrm{CHCl}_{3}, 22{ }^{\circ} \mathrm{C}\right) ; \mathrm{R}_{\mathrm{f}}\left(\mathrm{CH}_{2} \mathrm{Cl}_{2} / \mathrm{MeOH}\right.$ 98:2) 0.37; IR (neat) 3395 (m, br.), $2933(\mathrm{~m}), 1451(\mathrm{w}), 1266(\mathrm{~m}), 1146$ (s) cm ${ }^{-1} ;{ }^{1} \mathrm{H}$ NMR (400 MHz, $\left.\mathrm{CDCl}_{3}\right) \delta 3.23(1 \mathrm{H}$, app. spt, J 7.0 Hz), $3.16-3.07$ (2H, m, simplified as $1 \mathrm{H}, \mathrm{td}, J 9.8,4.7 \mathrm{~Hz}$ upon $\mathrm{D}_{2} \mathrm{O}$ shake), $2.36(1 \mathrm{H}$, ddd, $J 11.5,9.1,3.7 \mathrm{~Hz}), 2.11-2.00(2 \mathrm{H}, \mathrm{m})$ $1.81-1.62(2 \mathrm{H}, \mathrm{m}), 1.35-1.16(6 \mathrm{H}, \mathrm{m}), 1.04-0.88(1 \mathrm{H}, \mathrm{m}) \mathrm{ppm} ;{ }^{13} \mathrm{C} \mathrm{NMR}\left(100 \mathrm{MHz}, \mathrm{CDCl}_{3}\right) \delta 126.7(\mathrm{q}, J 281.7$ $\mathrm{Hz}), 74.3,63.8,53.5(\mathrm{q}, J 28.9 \mathrm{~Hz}), 32.9,32.0,25.2,24.2,16.4(\mathrm{q}, J 2.20 \mathrm{~Hz}) \mathrm{ppm} ;{ }^{19} \mathrm{~F} \mathrm{NMR}\left(376 \mathrm{MHz}^{\mathrm{C}} \mathrm{CDCl}_{3}\right) \delta-$ 78.09 (3F, d, $J 8.7 \mathrm{~Hz}$, simplified as s upon proton decoupling). MS [ESI $\left.{ }^{+}\right] 212[\mathrm{M}+\mathrm{H}]^{+}, \mathrm{HRMS}\left[\mathrm{ESI}^{+}\right]$for $\mathrm{C}_{9} \mathrm{H}_{16} \mathrm{~F}_{3} \mathrm{NO}$ $[\mathrm{M}+\mathrm{H}]^{+}$calcd. 212.1257, found 212.1261.

Data for diastereomer 2: $[\alpha]_{\mathrm{D}}-81$ (c 0.15, $\mathrm{CHCl}_{3}, 22{ }^{\circ} \mathrm{C}$ ); $\mathrm{R}_{\mathrm{f}}\left(\mathrm{CH}_{2} \mathrm{Cl}_{2} / \mathrm{MeOH}\right.$ 98:2) 0.24; IR (neat) 3322 (w, br.), 2923 (w, br.), $1454(\mathrm{w}), 1274(\mathrm{~m}), 1260(\mathrm{~m}) \mathrm{cm}^{-1} ;{ }^{1} \mathrm{H}$ NMR $\left(400 \mathrm{MHz}, \mathrm{CDCl}_{3}\right) \delta 3.30(1 \mathrm{H}$, app. spt, $J 7.0 \mathrm{~Hz}), 3.20(1 \mathrm{H}, \mathrm{td}, J$ 9.8, 4.5 Hz), $2.82-2.60\left(1 \mathrm{H}, \mathrm{m}\right.$, disappeared upon $\mathrm{D}_{2} \mathrm{O}$ shake), $2.36(1 \mathrm{H}$, ddd, $J 11.5,9.5,4.2 \mathrm{~Hz}), 2.12-1.90(2 \mathrm{H}, \mathrm{m})$, $1.80-1.67(2 \mathrm{H}, \mathrm{m}), 1.63-1.41\left(1 \mathrm{H}, \mathrm{m}\right.$, disappeared upon $\mathrm{D}_{2} \mathrm{O}$ shake), $1.36-1.15(6 \mathrm{H}, \mathrm{m}), 1.13-0.95(1 \mathrm{H}, \mathrm{m}) \mathrm{ppm}$; ${ }^{13} \mathrm{C}$ NMR $\left(100 \mathrm{MHz}, \mathrm{CDCl}_{3}\right) \delta 126.7(\mathrm{q}, J 281.0 \mathrm{~Hz}) 74.1,61.2,52.7(\mathrm{q}, J 28.6 \mathrm{~Hz}), 33.4,31.1,25.0,24.3,14.9(\mathrm{q}, J$ $2.20 \mathrm{~Hz}) \mathrm{ppm} ;{ }^{19} \mathrm{~F}$ NMR $\left(376 \mathrm{MHz}, \mathrm{CDCl}_{3}\right) \delta-78.0(3 \mathrm{~F}, \mathrm{~d}, J 6.9 \mathrm{~Hz}$, simplified as s upon proton decoupling) ppm; MS $\left[\mathrm{ESI}^{+}\right] 212[\mathrm{M}+\mathrm{H}]^{+} ; \mathrm{HRMS}\left[\mathrm{ESI}^{+}\right]$for $\mathrm{C}_{9} \mathrm{H}_{16} \mathrm{~F}_{3} \mathrm{NO}[\mathrm{M}+\mathrm{H}]^{+}$calcd. 212.1257, found 212.1261.

\section{Acknowledgement}

The European Community (INTERREG IVa Channel Programme, AI-Chem, project 4494/4196), the EPSRC (EP/K503150/1 and core capability EP/K039466/1), and the University of Southampton are thanked for financial support.

\section{Supporting Information}

2D spectra related to imine geometry assignment, determination of diastereomeric ratio's, copies of ${ }^{1} \mathrm{H},{ }^{13} \mathrm{C},{ }^{19} \mathrm{~F}$ NMR spectra of all novel compounds, X-ray crystallographic data of the reduction products and amine salts. This material is available free of charge via the Internet at http://pubs.acs.org/. 


\section{References}

(1) Raasch, M. S. J. Org. Chem. 1962, 27, 1406.

(2) Dickey, J. B.; Towne, E. B.; Bloom, M. S.; Taylor, G. J.; Wallace, D. J.; Sagal, J.; McCall, M. A.; Hedberg, D. G. Ind. Eng. Chem. 1956, 48, 209.

(3) Shepard, R. A.; Sciaraffa, P. L. J. Org. Chem. 1966, 31, 964.

(4) Ono, T.; Kukhar, V. P.; Soloshonok, V. A. J. Org. Chem. 1996, 61, 6563.

(5) Pfrengle, W.; Pees, K.-J.; Albert, G.; Carter, P.; Rehnig, A.; Van Tuyl Cotter, H.; US5986135, 1999.

(6) Zhang, X.; Zhang, N.; Chen, G.; Turpoff, A.; Ren, H.; Takasugi, J.; Morrill, C.; Zhu, J.; Li, C.; Lennox, W.; Paget, S.; Liu, Y.; Almstead, N.; Njoroge, F. G.; Gu, Z.; Komatsu, T.; Clausen, V.; Espiritu, C.; Graci, J.; Colacino, J.; Lahser, F.; Risher, N.; Weetall, M.; Nomeir, A.; Karp, G. M. Bioorg. Med. Chem. Lett. 2013, 23, 3947.

(7) Soloshonok, V. A.; Ono, T. J. Org. Chem. 1997, 62, 3030.

(8) Wu, Y.; Deng, L. J. Am. Chem. Soc. 2012, 134, 14334.

(9) Arnone, A.; Bravo, P.; Capelli, S.; Fronza, G.; Meille, S. V.; Zanda, M.; Cavicchio, G.; Crucianelli, M. J. Org. Chem. 1996, 61, 3375.

(10) Bravo, P.; Guidetti, M.; Viani, F.; Zanda, M.; Markovsky, A. L.; Sorochinsky, A. E.; Soloshonok, I. V.; Soloshonok, V. A. Tetrahedron 1998, 54, 12789.

(11) Robak, M. T.; Herbage, M. A.; Ellman, J. A. Chem. Rev. 2010, 110, 3600.

(12) Wang, H.; Zhao, X.; Li, Y.; Lu, L. Org. Lett. 2006, 8, 1379.

(13) Grellepois, F. J. Org. Chem. 2013, 78, 1127.

(14) Liu, Z.-J.; Liu, J.-T. Chem. Commun. 2008, 5233.

(15) Xu, J.; Liu, Z.-J.; Yang, X.-J.; Wang, L.-M.; Chen, G.-L.; Liu, J.-T. Tetrahedron 2010, 66, 8933.

(16) Kawanami, T.; Karns, A. S.; Adams, C. M.; Serrano-Wu, M. Tetrahedron Lett. 2013, 54, 7202.

(17) Review: Mei, H. B.; Xie, C.; Han, J. L.; Soloshonok, V. A. Eur. J. Org. Chem. 2016, 5917.

(18) Li, P.; Jiang, M.; Liu, J.-T. Chin. J. Chem . 2014, 32, 1003.

(19) Yang, Y.; Huang, Y.; Qing, F.-L. Tetrahedron Lett. 2013, 54, 3826.

(20) Wang, L.; Shen, Q.; Lu, L. Chin. J. Chem . 2013, 31, 892.

(21) Colyer, J. T.; Andersen, N. G.; Tedrow, J. S.; Soukup, T. S.; Faul, M. M. J. Org. Chem. 2006, 71, 6859.

(22) Hua, D. H.; Miao, S. W.; Chen, J. S.; Iguchi, S. J. Org. Chem. 1991, 56, 4.

(23) Zhang, W.; Sha, W.; Zhu, Y.; Han, J.; Soloshonok, V. A.; Pan, Y. Eur. J. Org. Chem. 2017, DOI: 10.1002/ejoc.201601645.

(24) Davis, F. A.; Kluger, E. W. J. Am. Chem. Soc. 1976, 98, 302.

(25) Liu, G. C.; Cogan, D. A.; Owens, T. D.; Tang, T. P.; Ellman, J. A. J. Org. Chem. 1999, 64, 1278.

(26) Cogan, D. A.; Liu, G. C.; Ellman, J. A. Tetrahedron 1999, 55, 8883.

(27) Cogan, D. A.; Ellman, J. A. J. Am. Chem. Soc. 1999, 121, 268.

(28) Barrow, J. C.; Ngo, P. L.; Pellicore, J. M.; Selnick, H. G.; Nantermet, P. G. Tetrahedron Lett. 2001, $42,2051$.

(29) Kochi, T.; Tang, T. P.; Ellman, J. A. J. Am. Chem. Soc. 2002, 124, 6518. 
(30) Kochi, T.; Tang, T. P.; Ellman, J. A. J. Am. Chem. Soc. 2003, 125, 11276.

(31) McMahon, J. P.; Ellman, J. A. Org. Lett. 2005, 7, 5393.

(32) Denolf, B.; Leemans, E.; De Kimpe, N. J. Org. Chem. 2007, 72, 3211.

(33) Use of TMSCl in MeOH: (a) Qian, X.; Tang, E.; Fan, J.; Zhu, K.; Zhu, J.; Shabaker, J.; Lo, E.; Malley, M.; Deshpande, R. Tetrahedron 2015, 71, 9408; (b) Guerin, D.; Dez, I.; Gaumont, A.-C.; Pannecoucke, X.; CouveBonnaire, S. Org. Lett. 2016, 18, 3606.

(34) Upthagrove, A. L.; Nelson, W. L. Drug Metab. Dispos. 2001, 29, 1377.

(35) Robin, A.; Brown, F.; Bahamontes-Rosa, N.; Wu, B.; Beitz, E.; Kun, J. F. J.; Flitsch, S. L. J. Med. Chem. 2007, 50, 4243.

(36) Das, U.; Crousse, B.; Kesavan, V.; Bonnet-Delpon, D.; Begue, J. P. J. Org. Chem. 2000, 65, 6749.

(37) Gnanamani, E.; Someshwar, N.; Sanjeevi, J.; Ramanathan, C. R. Adv. Synth. Catal. 2014, 356, 2219.

(38) Zhou, Y.; Wang, J.; Gu, Z. N.; Wang, S. N.; Zhu, W.; Acena, J. L.; Soloshonok, V. A.; Izawa, K.; Liu, H. Chem. Rev. 2016, 116, 422.

(39) Wang, J.; Sánchez-Roselló, M.; Aceña, J. L.; del Pozo, C.; Sorochinsky, A. E.; Fustero, S.; Soloshonok, V. A.; Liu, H. Chem. Rev. 2014, 114, 2432.

(40) O'Hagan, D. J. Fluorine Chem. 2010, 131, 1071.

(41) Purser, S.; Moore, P. R.; Swallow, S.; Gouverneur, V. Chem. Soc. Rev. 2008, 37, 320.

(42) Fujiwara, T.; O'Hagan, D. J. Fluorine Chem. 2014, 167, 16

(43) Jeschke, P. Pest Manag. Sci. 2010, 66, 10. 